\title{
MERETAS KORUPSI DALAM NEGARA DEMOKRASI (Sebuah Tawaran Hukum Islam melalui Konsep Istishlah)
}

\author{
N adir \\ (Fakultas H ukum U niversitas M adura Jl. Raya Panglegur km. 3,5 Pamekasan, \\ email: nadir@yahoo.co.id)
}

\begin{abstract}
A bstrak:
Korupsi merupakan kejahatan yang dipandang sebagai kejahatan tingkat tinggi, bukan saja karena kejahatan ini dilakukan secara sistematis, tetapi akibat yang ditimbulkan dari kejahatan ini paralel dan merusak seluruh sistem yang terkena virus korupsi tersebut. Karenanya, ia diperlukan sebuah penanggulangan yang menyeluruh dan sistematis baik melalui cara penal maupun non penal. A pabila selama ini cara penal tidak bisa membuat jera pelaku korupsi, maka langkah selanjutnya adalah dengan cara non penal yakni melalui moral virtue, yakni dengan membangun karakter kepribadian yang memotivasi seseorang secara instrinsik untuk tidak melakukan korupsi, karena ia dinilai moral sebagai sebuah kebenaran. Dalam hukum Islam, konsep moral virtue tersebut dikenal dengan konsep istishlah, yakni perbuatan seseorang yang mengarah kepada kebaikan atau kebutuhan manusia yang berdasarkan logika dipandang sebagai suatu kebenaran, walaupun tidak tercantum di dalam teks-teks suci.
\end{abstract}

\begin{abstract}
A bstract:
Corruption is the crime that is viewed as the high one, not only because it is done systimatically but its effect can be parallel and disturb all systems that is affected by its virus. Therefore, it is needed the whole and systematic solution both through penal or non-penal. If the penal way cannot make the corruptors daunted, so the next step is by non-penal namely moral virtue, by building the personal character that motivates anyone instinctive not to do the corruption because he thinks moral is honesty. In islamic law, the concept of moral virtue is known as istishlah, that is someone's act referring to the kindness or people's need based on the logic
\end{abstract}


that is viewed as an honesty, although it is not on the holy text.

\section{Kata Kunci :}

Korupsi, demokrasi, istishlah, dan moral virtue

\section{Pendahuluan}

Demokrasi mensyaratkan adanya pengakuan kedaulatan rakyat yang diwujudkan dalam bentuk pengakuan civil society sebagai kekuatan penekan dan pengimbang negara. Rakyat sebagai elemen utama civil society secara mutlak mendapatkan kedudukan strategis yang dijamin konstitusi untuk menjalankan peran-perannya sebagai bentuk partisipasi aktif dalam rangka memberantas perilaku koruptor.

Aneh dan ajaib, korupsi di negara di dunia selalu mendapat perhatian yang lebih jika dibandingkan dengan tindak pidana lainnya, karena ia erat kaitannya dengan kerugian dan kehancuran karakter negara. Fenomena ini dapat dimaklumi mengingat dampak negatif yang ditimbulkan oleh tindak pidana ini. Dampak yang ditimbulkan dapat menyentuh berbagai bidang kehidupan. Korupsi merupakan masalah serius yang dihadapi suatu bangsa, tindak pidana korupsi dapat membahayakan stabilitas perekonomian, politik, dan juga dapat merusak nilai-nilai demokrasi dan moralitas suatu bangsa, karena cepat atau lambat perbuatan ini sekan-akan menjadi budaya.

Selain itu, akibat dari tindak pidana korupsi yang sangat krusial adalah merusak sistem tatanan nilai suatu bangsa, dan yang jelas menghambat pembangunan nasional yang telah direncanakan. Tindak pidana korupsi merupakan ancaman terhadap cita-cita suatu bangsa dalam rangka menuju masyarakat madani. M ekanisme tindak pidana korupsi dilakukan dengan berbagai macam cara dan aneka bentuk yang direncanakan oleh sang koruptor dengan subjektif dan sistematis. Oleh karena itu, tidak heran jika tindak pidana ini sangat menjadi perhatian publik di berbagai negara.

Rukmini menilai korupsi senantiasa dipandang sebagai penyakit yang menular dan dapat berkembang biak dalam jaringan tertentu tidak dapat berhenti dalam satu jaringan melainkan 
Nadi $r$

berpindah dari satu jaringan ke jaringan lainnya hingga jaringan tersebut hancur seluruhnya. Korupsi merupakan kejahatan yang dipandang sebagai kejahatan tingkat tinggi, bukan saja karena kejahatan ini dilakukan melalui dan teknik yang sistematis, akan tetapi akibat yang muncul dari kejahatan ini paralel dan merusak seluruh sistem yang terkena virus korupsi tersebut.1

Sedangkan Romli Atmasasmita, sebagaimana dikutip Rukmini, menilai bahwa korupsi merupakan kejahatan yang luar biasa (extra ordinary crime). ${ }^{2}$ la sekal igus merupakam sebuah kejahatan yang sulit dicari penjahatnya (crime without offender), karena korupsi berada di wilayah yang sulit untuk ditembus. Korupsi bukan hanya merugikan keuangan Negara, tetapi juga berpotensi merusak sendisendi kehidupan sosial dan hak-hak ekonomi rakyat. Pada dasarnya Koruptor merampas uang rakyat; fakta bahwa korupsi sudah sedemikian meluas tidak saja terlihat dari persepsi masyarakat Indonesia, akan tetapi juga masyarakat internasional. Korupsi di Indonesia adalah penyakit yang sangat parah. Pandangan masyarakat Internasional yang dikemukakan oleh lembaga, organisasi yang secara khusus meneliti dan memantau praktik-praktik korupsi diberbagai negara hasinlya dapat dilihat bahwa Indonesia menempati peringkat paling parah dalam kelompok negara yang memiliki tingkat korupsi yang sangat tinggi. ${ }^{3}$

Demokrasi mensyaratkan adanya pengakuan kedaulatan rakyat yang diwujudkan dalam bentuk pengakuan civil society sebagai kekuatan penekan dan pengimbang vis a vis negara. Rakyat sebagai elemen utama civil society secara mutlak mendapatkan kedudukan strategis yang dijamin konstitusi untuk menjalankan peran-perannya sebagai bentuk partisipasi aktif.

\section{Kultur dan Sistem Hukum di Indonesia}

Pada hakikatnya sistem, termasuk sistem hukum, merupakan suatu kesatuan hakiki dan terbagi-bagi dalam bagian-bagian, di

1 Mien Rukmini, Aspek Hukum Pidana dan Kriminologi: Sebuah Bunga Rampai (Bandung: PT. Rosdakarya, 2006), hlm. 111

2 Romli Atmasasmita, Korupsi, Good Governance dan Komisi anti Korupsi di Indonesia (Jakarta: Badan Pembinaan Hukum Nasional, Departemen Hukum dan HAM RI, 2002), hlm. 9.

3 Lihat Rukmini, A spek Hu kum Pidana, hlm. 26 - 27. 
dalam mana setiap masalah atau persoalan menemukan jawaban atau penyelesaiannya. Jawaban itu terdapat di dalam sistem itu sendiri. ${ }^{4}$

Kalau seandainya di Negara hukum Republik Indonesia budaya hukumnya masih mengadopsi sistem hukum masyarakat adat, dan diterapkan di dalam kehidupan berbangsa dan bernegara dalam bentuk suatu kodifikasi, maka tentunya untuk memberantas korupsi lebih efektif dan lebih efisien. Bukankah menurut aliran sosiological jurisprudence, sebagaimana yang dikemukakan oleh Eugen Ehrlich, bahwa hukum yang dibuat harus sesuai dengan hukum yang hidup di dalam masyarakat (living law). Kalau mengindikasikan terhadap living law tentunya kehidupan masyarakat (orang) sebagai subjek hukum akan mengindahkan apa yang dirumuskan oleh para pembuat undang-undang.

Lemahnya substansi hukum (undang-undang) yang dibangun di Negara Indonesia dapat mengakibatkan lemahnya sutruktur aparat penegak hukum untuk menjerat para pelaku korupsi, sehingga dengan lemahnya substansi yang ada dapat dijadikan alasan pembenar oleh para pelaku korupsi (koruptor). Hal ini disebabkan Negara Indonesia terlalu rigid dengan konsep legal positivism di mana sebenarnya kita tahu bahwa undang-undang itu tidak lengkap dan tidak mungkin akan lengkap karena perkembangan peradaban intelektual manusia dan sekaligus juga sebagai pelaku hukum selalu berkembang seiring dengan perkembangan ilmu pengetahuan dan teknologi.

A roma formalisme, legisme, kapital isme, dan liberal isme yang menjadi trade mark hukum Indonesia saat ini, pada dasarnya merupakan bagian yang tidak dapat dipisahkan dari sejarah perkembangan hukum modern, yang bergerak sangat massif di Eropa Barat pada abad ke-17 $\mathrm{M}$ hingga abad ke-18 $\mathrm{M}$ beriringan dengan munculnya negara-negara bangsa atau negara modern. Selanjutnya hukum modern menempatkan negara sebagai otoritas penafsir tunggal "ditransplantasikan" di Indonesia. Proses transplantasi itu pada kenyataannya tidak hanya membawa model institusi dan aturannya saja, tetapi sekaligus jiwa hukum yang

4 Sudikno Mertokusumo, M engenal Hukum: Suatu Pengantar, (Yogyakarta: Liberty, 2005), hlm. 123. 
Nadi $r$

beraroma kapitalis, liberalis, dan legalis tersebut, yang pada tahap selanjutnya membawa habis struktur sosial masyarakat Indonesia yang sangat kaya dan beragam (pluralis). Tidak cukup hanya di situ, hukum modern itu kemudian menggusur cara penyelesaian yang sudah ada pada masyarakat sebelumnya, maka dimulailah kehidupan hukum yang dipenuhi dengan situasi objek dan noise berbau formalisme, di mana fokus utamanya berfokus pada prosedur dan menempatkan Negara sebagai satu-satunya klaim kebenaran. Hal ini tampak dari lebelisasi semua atribut keadilan, polisi, jaksa, pengacara, hakim dan seterusnya. Kebenaran akan bernilai apabila prosedur telah dijalankan, yang pada tahap-tahap selanjutnya lembagalembaga hukum yang hanya bertugas memberikan keadilan secara prosedural, keadilan dalam teks undang-undang, keadilan dalam bentuk formal dan jauh dari keadilan substansial.5

Ada sebuah ungkapan yang sangat indah sebagaimana yang dikatakan Satjipto Rahardjo, "lihat nurani, nurani kita, nurani anda, nurani bangsa". Benar-benar sebuah ungkapan yang sangat indah dari seorang Profesor yang telah banyak memberikan sumbangan pemikiran tentang hukum di negara kita Indonesia. Namun kita tahu para koruptor itu rata-rata tidak memiliki moral virtue apalagi hati nurani yang ada di kepala mereka adalah uang-uang, bagaimana caranya mereka mendapatkan uang yang banyak tanpa menghiraukan aspek-aspek lainnya yang mengakitakan kelumpuhan terhadap prekonomian nasional. Mereka (koruptor) bisa dikatakan termasuk orang yang tidak memiliki etika bahkan saya kira dia sudah melepaskan agamanya dari jiwa mereka (korutor), seandanya mereka mengetahui, mengerti dan memahami betapa beratnya siksa Tuhan Yang Maha Kuasa (Allah) di hari akhirat nanti. Mungkin mereka (koruptor) tidak akan melakukan korupsi karena korupsi pada dasarnya adalah maling negara.

Kerakusan dan membiarkan perilaku korupsi adalah seperti seseorang yang menunggang macan; ingat Riding the Tiger- sebuah judul film dokumenter dari Australia yang dibuat oleh Curtis levy dan Christine Olson. Orang yang rakus dan korup itu akan berada di atas sebuah perkembangan kehidupan yang bisa jahat terhadap

5 Rukmini, A spek H ukum Pidana, hlm. 120-121 
dirinya. Ibarat menaiki macan, jika ia turun bisa saja ia dicakar si raja hutan itu. Sebaliknya bila ia terus, ia mungkin saja tak akan bisa mengendalikannya, sampai ia tersungkur ke dalam jurang yang dalam. Bila suatu saat ketahuan ia bertindak korup, imbalannya sangat berat. Ia akan diisolasi dan dianggap sampah terbau oleh masyarakat yang mendamba kejujuran. Sekali lancung di ujian seumur hidup orang tak percaya. Penyesalan panjang di hari tua dan ketika ajal menjemput. Generasi senior, kelompok pekerja keras dan kalangan cendikia perlu berjuang merintis semangat menjinakkan korupsi di negeri ini agar perbaikan kehidupan agar generasi yang lebih yunior di waktu yang akan datang bisa hidup lebih baik, lebih demokratis dan lebih makmur dari generasi terdahulu, dan itulah yang disebut perjuangan kemanusian dan peradaban. Sebab utama korupsi adalah nafsu untuk hidup mewah dalam kelompok yang memerintah. Korupsi pada kelompok penguasa menyebabkan kesulitan-kesulitan ekonomi dan kesulitan ini pada gilirannya menjangkitkan korupsi lebih lanjut. Justru karena itu pemberantasan korupsi harus dimulai dari akarnya, yaitu kelompok yang memerintah dan penanggulangannya harus pula dengan melibatkan seluruh kelompok tersebut. 6

\section{Penanggulangan Korupsi dengan Pendekatan Moral Virtue (Istishlah)}

Secara kultural dan struktural memberantas korupsi adalah mensosialisasikan nilai baru bahwa korupsi merupakan sebuah tindakan yang beresiko tinggi dan bernilai rendah, dan akan dikenakan pembuktian terbalik bahwa harta yang diperolehnya adalah barang yang halal. Secara struktural memberantas korupsi berarti memberantas KKN dengan memberdayakan Komisi Pemeriksaan Kekayaan Pejabat dan latar belakang kehidupannya, membangun sistem pencegah dini korupsi, Undang-undang Nomor 20 Tahun 2002 tentang Anti Korupsi yang konsisten, memberikan jaminan hidup yang layak bagi pegawai, sistem pembuktian terbalik, pengumuman dan audit kekayaan pejabat sebelum dan sesudah bertugas, membuat iklan layanan masyarakat di media massa dan di kemasan produk-produk yang dikonsumsi semua orang.

${ }^{6}$ Syafuan Rozi, M enjinakkan K orupsi di Indonesia, (Jakarta: PPW LIPI , 2004), hlm.2 
Nadi $r$

Para penguasa Negara Indonesia ini perlu banyak belajar dan merenung untuk menghargai bahwa korupsi merugikan orang banyak yang telah bekerja keras dan berlaku jujur. Tindakan korupsi tidak menghargai fitrah manusia yang diilhamkan kepadanya untuk cinta kepada kebaikan. Dengan begitu kita semua sedang belajar untuk hidup lebih lurus. Anak bangsa ini lahir dan besar dalam kondisi majemuk dan berbeda status sosial ekonominya. A da yang berpunya dan ada yang lahir dalam serba berkekurangan. Dalam kemajemukaan tersebut, keragaman pandangan dan pilihan untuk memelihara dan menjinakkan perilaku korupsi adalah hal biasa dan harus dihargai. Dengan kemauan mengkoreksi kesalahan berarti kita berpeluang untuk mengatasi krisis apa pun. Krisis adalah peluang di masa sulit. Bangsa ini perlu membangun kehidupan sehari-hari yang berdasar etika yang kuat, aturuan-aturan hukum yang dibuat aspiratif dan partisipatif, dengan begitu keadilan akan datang. ${ }^{7}$

Perilaku korupsi bisa diindikasikan dari berbagai perspektif atau pendekatan. Tindakan korupsi menurut perspektif keadilan atau pendekatan hukum misalnya mengatakan bahwa korupsi adalah mengambil bagian yang bukan menjadi haknya. Korupsi adalah mengambil secara tidak jujur perbendaharaan milik publik atau barang yang diadakan dari pajak yang dibayarkan masyarakat untuk kepentingan memperkaya dirinya sendiri. Korupsi adalah tingkah laku yang menyimpang dari tugas-tugas resmi suatu jabatan secara sengaja untuk memperoleh keuntungan berupa status, kekayaan atau uang untuk perorangan, keluarga dekat atau kelompok sendiri. Perspektif atau pendekatan relatifisme kultural yang strukturalis, bisa saja mengatakan pemaksaan untuk menyeragamkan berbagai pemerintahan lokal, menyebabkan budaya asli setempat tidak berkembang, melemahkan keberadaannya untuk diganti dengan budaya yang dominan milik penguasa adalah tindakan korupsi struktural terhadap persoalan kultural. Pendekatan atau perspektif orang awam dengan lugas mengatakan bahwa menggelapkan uang kantor, menyalahgunakan wewenangnya untuk menerima suap, menikmati gaji buta tanpa bekerja secara serius adalah tindakan korupsi. Bisa saja hal itu dikatakan untuk menjelaskan hal yang kita benci dan akan kita jinakkan. Menghilangkan korupsi bukanlah

7 lbid. hlm. 3 
perkara gampang karena ia telah berurat berakar dan menjalar kemana-mana di negeri kita ini. Tidak semua orang rela jalan pintasnya untuk kaya diungkit-ungkit. Ada lagi yang menjelaskan bahwa mereka korupsi kecil-kecilan karena terpaksa oleh keadaan. Gaji kecil yang tidak mencukupi untuk hidup yang layak dari bulan ke bulan menjadi alasan untuk membenamkan diri. Apalagi kalau hampir semua orang di tempat itu telah menganggap hal itu adalah hal yang biasa. Tahu sama tahu, untuk tidak mengatakan atasan mereka juga melakukan hal yang sama. ${ }^{8}$

Apabila dengan cara penal tidak bisa membuat jera pelaku korupsi di Indonesia, maka langkah selanjutnya adalah dengan cara moral virtue, yaitu dengan cara meningkatkan langkah-langkah meningkatkan moral bangsa karena korupsi tidak hanya ada di lembaga eksekutif, legislatif, dan yudikatif melainkan sudah merambah ke semua sektor.

Apakah moral virtue itu. Georg Spielthenner mendefinisikannya sebagai sebuah ciri atau karakter kepribadian yang memotivasi seseorang secara instrinsik untuk bertindak dalam sebuah situasi spesifik yang dinilai secara moral sebagai sebuah kebenaran. ${ }^{9}$ Inilah yang membedakan virtue, misalnya, dengan kebiasaan (habits), kemampuan (abilities), bakat (talents), dan temperamen (temperament) seseorang.

Dari definisi di atas dapat dijelaskan beberapa hal, yaitu: Pertama, Virtue memotivasi seseorang secara instrinsik. Jika seorang yang baik mengetahui bahwa rakyat Indonesia masih banyak yang berada di bawah garis kemiskinan, ia tidak akan mengkorupsi uang rakyat yang dikelola negara. Motivasi tersebut bersifat intrinsik. Ia tidak hanya termotivasi untuk tidak mengambil uang rakyat, sebab ia percaya bahwa tindakan yang demikian, misalnya, akan banyak membantu rakyat miskin keluar dari kondisi kemiskinannya.

Kedua, moral virtue adalah ciri kepribadian yang memotivasi seseorang dalam situasi spesifik untuk bertindak dengan sebuah cara tertentu. Artinya, virtue berkaitan dengan keadaan spesifik dalam

8 lbid.

9 Georg Spielthenner, “Moral Virtues”, ethic@, Florianópolis, Vol. 3,No.1 (Juni, 2004), hlm. 27 
Nadi $r$

kehidupan seseorang. Jika seorang pejabat yang jujur memiliki peluang yang sangat besar untuk melakukan korupsi, tentu ia tidak akan menggunakan kesempatan tersebut. Kalau pun ia terlanjur melakukan korupsi karena tekanan sistem yang berlaku, ia akan mengembalikan uang yang dikorupsi tersebut.

Ketiga, virtue memotivasi untuk bertindak dalam sebuah situasi spesifik yang secara umum dan moral benar. Dalam hal ini perlu dibedakan antara tindakan yang benar secara subyektif dan obyektif. Seseorang yang bertindak secara moral dan obyektif benar dalam sebuah situasi spesifik jika ia melakukan apa yang seharusnya ia lakukan, sesuai dengan sudut pandang etis-normatif. Sedangkan seseorang yang bertindak secara moral dan subyektif benar dalam sebuah situasi spesifik jika ia melakukan apa yang ia percaya sebagai kebenaran obyektif. M oral virtue memotivasi kepada tindakan yang secara obyektif benar.

Dalam hukum Islam, konsep moral virtue tersebut dapat disepadankan dengan istishlah. Secara bahasa, ia adalah perbuatanperbuatan yang mendorong kepada kebaikan manusia, baik dalam arti menarik atau menghasilkan keuntungan atau kesenangan atau dalam arti menolak kemadharatan atau kesusahan.10 Sebagaimana moral virtue, ia adalah perbuatan seseorang yang mengarah kepada kebaikan atau kebutuhan manusia yang berdasarkan logika dipandang sebagai suatu kebenaran, walaupun tidak tercantum di dalam teks-teks suci. Ia menjadikan kepentingan publik (public interest) sebagai landasan etis-normatif untuk melakukan suatu tindakan.

Landasan pemikiran yang membentuk konsep ini adalah kenyataan yang mudah ditangkap bahwa syarî'ah Islam dalam berbagai pengaturan dan hukumnya mengarah kepada terwujudnya mashlahah. Karenanya, upaya mewujudkan mashlahah dan mencegah mafsadah (hal-hal yang merusak) adalah sesuatu yang sangat nyata dibutuhkan setiap orang. ${ }^{11}$

10 N asrun Haroen, U shul F iqh I,(Ciputat: P.T. Logos Wacana IImu, 1997), hlm 113.

${ }^{11}$ A li Yafie, K ontekstualisasi D oktrin Islam dalam Sejarah: Konsep-konsep Istihsan, Istishlah, dan Mashlahat Al-Ammah, ed. Budhy Munawar-Rachman, Jakarta: Yayasan paramadina, 1994), hlm 365. 
Untuk menentukan apakah sebuah persoalan termasuk ke dalam kategori mashlahah atau mafsadah, harus dikembalikan atau dilihat unsur yang menunjukkan angka dominan di antara keduanya. Ini didasarkan pada suatu pemikiran bahwa tidak ditemukan di dunia suatu mashlahah yang tidak diikuti oleh mafsadah, sebagaimana juga tidak ada mafsadah tanpa mengandung nilai-nilai mashlahah di dalamnya. ${ }^{12}$ Persoalan korupsi, misalnya, adalah perbuatan yang secara logika merugikan kepentingan publik, dan karenanya ia dikategorikan sebagai mafsadah.

Pendekatan istishlah atau moral virtue di atas harus dapat diartikan sebagai sikap antisipatif terhadap sistem birokrasi kenegaraan secara komprehensif. Perlu disadari tanpa adanya komitmen dan kesadaran etika serta moral virtue dari semua aparat penegak hukum, maka keutuhan substansi dan struktur dari sistem hukum tidak akan berarti

Memasuki era pembaruan hukum melalui kajian penerapan substansi hukum, tanpa didukung dengan peningkatan budaya hukum dan moral virtue dari aparat penegak hukum, maka tindak pidana korupsi hanya akan menjadi kisah seribu cinta dunia maya.

Untuk memberantas korupsi di Indonesia memang tidak semudah membalik telapak tangan. Namun bisa dilakukan sedikit demi sedikit secara bertahap. Perbuatan korupsi dapat diberantas dari negara Indonesia atau sekurang-kurangnya dapat ditekan sampai tingkat minimal dengan melakukan beberapa langkah sebagai berikut: Pertama, pembenahan hukum yang berlaku. Saat ini terlampau banyak celah dan kelemahan yang dapat dimanfaatkan oleh koruptor, sehingga banyak koruptor yang tidak terjamah oleh Undang-Undang Pemberantasan Tindak Pidana Korupsi. Seharusnya yang juga dapat dijerat dengan Undang-Undang Nomor 20 Tahun 2001 termasuk keluarga pejabat atau orang-orang yang mempunyai hubungan langsung atau tidak langsung dengan tidak pidana tersebut, mereka seharusnya juga dapat dijerat dengan undangundang ini, sehingga semua pihak yang terlibat dapat dijerat tanpa

12 Mun'im A. Sirry, “Memperkenalkan Fiqh Abu Ishaq al-Syathibi”, Jurnal U lumul Qur'an, Vol. V N o. 1 (1999), hlm. 81. 
Nadi $r$

terkecuali, tidak hanya pelaku, tetapi juga yang turut melakukan, yang menyuruh melakukan dan yang membantu melakukan.

Kedua, penerapan hukum secara profesional dan proporsional. Seharusnya dalam pelaksanaan sistem hukum negara Indonesia jangan ada perbedaan perlakuan (diskriminasi) dalam bentuk apa pun dan terhadap siapa pun, dalam proses penegakan hukum misalnya terhadap orang yang dikenakan penahanan, baik orang biasa maupun pejabat harus diberlakukan sama sesuai dengan ketentuan Pasal 21 sampai dengan Pasal 29 KUHAP. Sedangkan pejabat yang telah memiliki bukti awal yang cukup seharusnya segera dimasukkan dalam tahanan. Pelaku kriminal lainnya hanya boleh menjenguk pada jam dan waktu yang telah ditentukan dan koruptor harusnya juga diperlakukan sama. Seringkali pihak aparat penegak hukum seolah-olah kalah wibawa dengan koruptor, hal ini mengindikasikan perlu segera dilakukan pembenahan moral dan mental para aparat penegak hukum yang terkait.

Ketiga, kontrol sosial masyarakat. Saat ini yang terjadi pelibatan masyarakat dalam upaya pemberantasan korupsi sangat terbatas pada LSM yang konsen dalam pemberantasan korupsi, Namun sangat minim pelibatan masyarakat secara komprehensif dikarenakan mereka enggan takut bahaya ancaman psikis, dan nyawa. Disadari atau tidak, bahwa pada dasarnya upaya pemberantasan tindak pidana korupsi harus melibatkan semua aspek lapisan masyarakat sebagai penopang aparat penegak hukum dengan jaminan perlindungan kepada masyarakat. Dengan keterlibatan masyarakat secara luas, maka secara tidak langsung upaya pemberantasan tindak pidana korupsi sudah bisa dilaksanakan dengan sistem dan mekansisme serta tatanan yang memadai.

Keempat, kepedulian dan keberanian masyarakat Seringkali masyarakat mengetahui tentang adanya perbuatan korupsi, tetapi tidak tahu harus melapor ke mana dan kepada siapa, juga ketakutan untuk dijadikan saksi yang akan merepotkan bahkan menyita waktu secara sia-sia, walaupun Undang-undang mewajibkan seseorang untuk menjadi saksi, tetapi karena kekawatiran adanya ancaman dan/atau teror yang akan datang di kemudian hari, baik selama maupun setelah proses peradilan, akhirnya orang tersebut menjadi takut dan enggan untuk menjadi saksi. Meskipun ada Undang- 
undang N omor 13Tahun 2006 hanya menjamin dan melindungi saksi mulai tahap penyidikan sampai putusan saja. Hadirnya Lembaga Perlindungan saksi dan Korban (LPSK) atas amanat undang-undang tersebut tidak begitu menjamin keselamatan nyawa dan harta serta kehormatan saksi.

Kelima, netralitas aparat penegak hukum. Komisi Pemberantasan Korupsi (KPK) dan mereka telah bekerja dengan semangat baru, meskipun itu belum cukup, dan sejauh ini kinerja mereka terus mendapatkan sorotan publik, sebagai contoh kasus Bank Century, Wisma Atlet, bidang pajak, dan lain-lain. Satu hal yang sangat penting, KPK harus bertindak kreatif dan berani mendobrak tradisi hukum kita yang sudah mapan, legalistik, dan berbau formalisme sebagaimana yang dijelaskan di atas. KPK harus menciptakan cara baru guna menyelesaikan masalah dan bukan sebaliknya, yakni menimbulkan masalah. Apalagi dalam kepemimpinan ketua KPK yang baru juga tersandung kasus korupsi. Dugaan tersebut ternyata terbukti dengan ditangkapnya Antasari selaku ketua KPK atas tuduhan dibalik pembunuhan Nasruddin yang ke semua itu berujung pada ditahannya A ntasari yang pada akhirnya pula terjadi adu dua kekuatan antara KPK dan Polri yang akhirnya beberapa anggota KPK juga ikut diperiksa. Oleh karena iu, apa salahnya menyampaikan hukum yang berbau formalisme, legisme dan liberalisme, karena hanya dengan cara demikian, maka hambatan-hambatan dapat diatasi.

Dalam melakukan pemberantasan tindak pidana korupsi faktor aparat penegak hukum dalam menegakkan hukum dan keadilan menjadi faktor esensial, karena aparat penegak hukum termasuk bagian dari struktur yang menjalankan atau sebagai pengawas Undang-undang dalam hal ini civil law sistem. Undangundang merupakan kumpulan kata dan/ atau kalimat yang penuh dengan makna dan nilai-nilai yang harus dijalankan oleh setiap masyarakat hukum, namun tanpa adanya faktor struktur aparat penegak hukum, dengan kualitas yang memadai, maka undangundang akan kehilangan esensinya, walaupun Undang-undang mengandung sanksi-sanksi yang mengikat. 
Nadir

\section{Penutup}

Dari beberapa uraian singkat yang telah dipaparkan di atas, maka kesimpulannya adalah bahwa: Pertama, penanggulangan korupsi sejak dini tidak cukup dengan penalisasi saja melainkan dengan non penal di mana dalam hal ini melakukan sosialisasi kepada setiap elemen masyarakat birokrasi sebagai penguatan keimanan dan ketaqwaan kepada Tuhan Yang Maha Esa (Allah swt.) yang merupakan tempat bersandar dan berserah diri serta kembalinya manusia kepadanya sebagai penyegaran batin diri manusia agar tidak melakukan perbuatan korupsi dengan semaunya.

Kedua, pembaharuan terhadap substansi sistem hukum di Indonesia yang selama ini besar kemungkinan masih dijadikan alasan pembenar oleh pihak koruptor untuk menghindar dari jeratan hukum yang ada, tanpa adanya sebuah pembaharuan hukum yang ada kecil kemungkinan untuk menjerat pelaku korupsi.

Ketiga, bahaya korupsi sangat luar biasa karena akibat yang ditimbulkan dan dirasakan oleh masyarakat warga (civil society) sangat membinasakan bahkan memiskinkan negara. Oleh karena itu, jika pencegahan sudah dilakukan sejak dini dengan beberapa cara baik dengan penal maupun non penal. Tawaran hukum Islam dalam penanggulangan secara non penal adalah melalui konsep istishlah atau moral virtue. Pendekatan moral virtue atau istishlah merupakan sebuah pendekatan alternatif yang dinilai mampu mencegah secara dini perilaku korupsi. Wallâh a'lam bi al-shawâb.

\section{D aftar Pustaka:}

Atmasasmita, Romli. Korupsi, Good Governance dan Komisi anti Korupsi di Indonesia. Jakarta: Badan Pembinaan Hukum Nasional, Departemen Hukum dan HAM RI., 2002

Haroen, Nasrun. U shul Figh I. Ciputat: P.T. Logos Wacana IImu, 1997.

Mertokusumo, Sudikno. Mengenal Hukum: Suatu Pengantar. Yogyakarta, Liberty, 2005.

Rozi, Syafuan. M enjinakkan Korupsi di Indonesia. (Jakarta: PPW LIPI Jakarta, 2004.

Rukmini, Mien. Aspek Hukum Pidana dan Kriminologi, Sebuah Bunga Rampai. Bandung: Alumni, 2006. 
Sirry, Mun'im A. "Memperkenalkan Fiqh Abu Ishaq al-Syathibi". Jurnal U lumul Q ur'an, Vol. V No. 1 (1999)

Spielthenner, Georg. “Moral Virtues”, ethic@, Florianópolis, Vol. 3,No.1 (Juni, 2004).

Yafie, Ali. Kontekstualisasi Doktrin Islam dalam Sejarah: Konsep-konsep Istihsan, Istishlah, dan M ashlahat A I-A mmah, ed. Budhy MunawarRachman. Jakarta: Yayasan paramadina, 1994. 